\title{
Autoerotic death: a rare but recurrent entity
}

\author{
Roger W. Byard
}

Accepted: 31 January 2012

(C) Springer Science+Business Media, LLC 2012

Autoerotic death has been defined as accidental death occurring during solitary sexual activity that results from a malfunction or an unexpected effect of a device/material or substance that was being used to augment the experience [1]. Although it has been recognized for over 200 years [2], cases in the literature have previously been mistaken for suicide, and a clear definition was not published until 1991 [3]. While our understanding of this entity has improved, diagnostic difficulties persist and there appears to have been recent changes in epidemiological features in certain communities.

A variety of different activities may be used to enhance sexual excitement that may be potentially lethal, including cross-dressing in conditions of extreme heat and inserting rectal and genital foreign bodies, however the majority of fatalities involve activities that induce asphyxia $[4,5]$. The basis for this is that oxygen deprivation augments the sexual response in certain individuals, giving rise to a variety of techniques being used to induce hypoxia during solitary or shared sexual activity. Given the often elaborate paraphernalia that is found at death scenes in cases of autoerotic asphyxia it is clear, however, that there are also often quite prominent elements of fetishism, bondage and masochism. An important point in cases of autoerotic death is that the manner of death is accidental. This means that cases where death has occurred from underlying organic

\footnotetext{
R. W. Byard

School of Medical Sciences, The University of Adelaide, Adelaide, Australia

R. W. Byard ( $\square)$

Discipline of Anatomy and Pathology, Level 3 Medical School

North Building, The University of Adelaide, Frome Road,

Adelaide 5005, Australia

e-mail: roger.byard@sa.gov.au
}

illness such as cardiovascular disease should not be included within this group [3].

One of the features used to diagnose autoerotic death is the presence of a 'fail safe' device at the scene [6]. This refers to a mechanism that enables the practitioner to free him or herself from any device that was being utilized to induce asphyxia. Unfortunately 'fail safe' devices are often quite fallible and following their failure, unconsciousness may develop very rapidly if the neck is compressed preventing self extrication [7].

Certain problems may arise in making the diagnosis of autoerotic death. By its very nature the activity is secretive, and so its practice by the victim may have been completely unknown to family members, who may then strongly resist the suggestion. Family members or friends may also alter the findings at the death scene before investigating police attend, due to the perceived stigma attached to such a death. Cases involving females are rare and are made more difficult by the lack of props and sexual paraphernalia that characterize such activities in males [8-10]. Studies have shown that practitioners may be depressed and so there exists the possibility that an individual who has previously engaged in this type of activity may elect to use this as a method of suicide. In the absence of a suicide note, or other evidence of a deliberate self destructive act, this possibility may be overlooked [11]. While the "Choking Game" played by adolescents to induce a euphoric effect uses hypoxia, it is distinguished from autoerotic activities by the absence of associated sexual activities [12].

Although the finding of a complex apparatus at a death scene may point to an autoerotic misadventure, certain suicides may also be characterized by very elaborate preparation with unusual devices [13]. However, careful assessment of the death scene should enable differentiation between these two events. One of the features at the death 
scene that may be useful in establishing the diagnosis of autoerotic misadventure may be evidence of repetitive activity of a similar nature. This may be in the form of worn grooves from ropes around an overhead beam in the garden shed where the decedent was found [1]. Unfortunately attempts to find tissue markers of previous hypoxic event in cases of known fatal sexual asphyxia have failed [14].

Typical cases of sexual asphyxia in the literature have involved young males aged between 15 and 25 years with an estimated incidence of 2-4 cases per million in the United States, and 1-2 cases per million in Scandinavia $[15,16]$. A recent review of national Australian and Swedish data, however, showed a lower rate (of approximately 0.3 cases per million of the population per year), with the most common age of the Australian victims being between 30 and 39 years [17]. Certainly death from sexual asphyxia has occurred in the elderly [18], however the Australian data may indicate that the epidemiological features of autoerotic death vary depending on the particular community that is being studied. This is something to be born in mind in the evaluation of cases. A marked male predominance has been a feature of all studies to date.

Although it is well recognized, autoerotic death remains a relatively rare entity characterized by unusual sexual behavior utilizing a wide variety of lethal mechanisms that most often involve asphyxia. While the typical case is of a young cross-dressing male found hanging in an isolated place surrounded by pornography, distinct variations from this stereotype occur [19]. The isolated nature of the activity may also result in artifacts from decomposition arising that may complicate the assessment of possible injuries. Differences in presentation should be borne in mind when unusual cases of hanging are being evaluated so that sexual asphyxia will not be overlooked.

\section{References}

1. Byard RW. Autoerotic death-characteristic features and diagnostic difficulties. J Clin Forensic Med. 1994;1:71-8.
2. The Marquis de Sade. Justine, or the misfortunes of virtue. New York: Castle Books; 1964. p. 101.

3. Byard RW, Bramwell NH. Autoerotic death. A definition. Am J Forensic Med Pathol. 1991;12:74-6.

4. Byard RW, Eitzen DA, James R. Unusual fatal mechanisms in nonasphyxial autoerotic death. Am J Forensic Med Pathol. 2000;21:65-8.

5. Byard RW, Kostakis C, Pigou PE, Gilbert JD. Volatile substance use in sexual asphyxia. J Clin Forensic Med. 2000;7:26-8.

6. Shields LB, Hunsaker DM, Hunsaker JC III. Autoerotic asphyxia: part I. Am J Forensic Med Pathol. 2005;26:45-52.

7. Gilbert J, Jensen L, Byard RW. Further observations on the speed of death in hanging. J Forensic Sci. 2008;53:1204-5.

8. Byard RW, Bramwell NH. Autoerotic death in females. An underdiagnosed syndrome? Am J Forensic Med Pathol. 1988;9: $252-4$.

9. Byard RW, Hucker SJ, Hazelwood RR. Fatal and near-fatal autoerotic asphyxial episodes in women. Characteristic features based on a review of nine cases. Am J Forensic Med Pathol. 1993;14:70-3.

10. Byard RW, Hucker SJ, Hazelwood RR. A comparison of typical death scene features in cases of fatal male and female autoerotic asphyxia with a review of the literature. Forensic Sci Int. 1990;48:113-21.

11. Byard RW, Botterill P. Autoerotic asphyxial death—accident or suicide? Am J Forensic Med Pathol. 1998;19:377-80.

12. Egge MK, Berkowitz CD, Toms C, Sathyavagiswaran L. The choking game. A cause of unintentional strangulation. Pediatr Emerg Care. 2010;26:206-8.

13. Austin AE, Heath K, Gilbert J, Byard RW. Head impalement—an unusual form of suicide. J Forensic Leg Med. (in press).

14. Byard RW, Masoumi H, Haas E, Sage M, Krous HF. Could intraalveolar hemosiderin deposition in adults be used as a marker for previous asphyxial episodes in cases of autoerotic death? J Forensic Sci. 2011;56:627-9.

15. Burgess AW, Hazelwood RR. Autoerotic asphyxial deaths and social network response. Am J Orthopsychiatry. 1983;53:166-70.

16. Innala SM, Ernulf KE. Asphyxiophilia in Scandinavia. Arch Sex Behav. 1989;18:181-9.

17. Byard RW, Winskog C. Autoerotic death: incidence and age of victims-a population based study. J Forensic Sci. 2012;57: 129-31.

18. Sauvageau A, Geberth VJ. Elderly victim: an unusual autoerotic fatality involving an 87-year-old male. Forensic Sci Med Pathol. 2009;5:233-5.

19. Shields LB, Hunsaker DM, Hunsaker JC III, Wetli CV, Hutchins KD, Holmes RM. Atypical autoerotic asphyxia: part II. Am J Forensic Med Pathol. 2005;26:53-62. 